Article

\title{
Total Stem and Merchantable Volume Equations of Norway Spruce (Picea abies (L.) Karst.) Growing on Former Farmland in Sweden
}

\section{Tord Johansson}

Department of Energy and Technology, Swedish University of Agricultural Sciences, Uppsala 75007, Sweden; E-Mail: tord.johansson@slu.se; Tel.: +46-18-673830; +46-18-673156

Received: 3 March 2014; in revised form: 21 July 2014 / Accepted: 19 August 2014 /

Published: 22 August 2014

\begin{abstract}
An equation was constructed to estimate the stem volume of Norway spruce (Picea abies (L.) Karst.) in 145 stands growing on former farmland in Sweden (Latitude $56-63^{\circ} \mathrm{N}$ ). The mean total age was $40 \pm 13$ (range 17-91) years, the mean diameter at breast height $(\mathrm{ob})$ was $15 \pm 4$ (range 5-27) cm and the mean density was $1621 \pm 902$ (range 100-7600) stems $\mathrm{ha}^{-1}$. The equation which fits the data best used the diameter at breast height and total stem height as predictive variables. Merchantable volume equations for the estimation of commercial volume for any top diameter and bole length were developed. Soil types in the stands were sediments (coarse sand, fine sand and silt and heavy, medium and light clay), tills (sandy, fine sandy and silty) and peat. The standing volume was calculated; the mean was $253 \pm 103$ (range 26-507) $\mathrm{m}^{3}$ ha $^{-1}$ with a MAI (mean annual increment) of $6.9 \pm 3.5$ (range 1.3-16.7) $\mathrm{m}^{3} \mathrm{ha}^{-1}$ year ${ }^{-1}$. There were statistically significant differences between MAI and coarse sand, sand and silt, light clay, peat and silty till soils. Spruce stands growing on silty tills had the lowest MAI (4.94 \pm $2.27 \mathrm{~m}^{3} \mathrm{ha}^{-1}$ year $\left.^{-1}\right)$ and light clay, fine sand and silt and peat the highest (7.62 $\pm 4.24,7.46$ \pm 3.33 and $8.67 \pm 2.83 \mathrm{~m}^{3} \mathrm{ha}^{-1}$ year $^{-1}$ ).
\end{abstract}

Keywords: equation; farmland; merchantable volume; Norway spruce; Picea abies; production; soil type; stem volume 


\section{Introduction}

Over the last 50 years, programs targeted at reducing agricultural production have been introduced in Sweden. The first program started in 1966, with the intention of planting about 500,000 ha of former farmland with forest trees, mainly Norway spruce (Picea abies (L.) Karst.). The second program of afforestation of farmland started in 1987, with a decision to take around 800,000 to 900,000 ha out of agricultural production. At this time, the farmland was mostly planted with broadleaved species as public opinion was very negative about the "dark" Norway spruce plantations created by the first afforestation program. The most frequently planted species were birch (Betula pendula Roth and Betula pubescens Ehrh.), hybrid aspen (Populus tremula $\times$ Populus tremuloides), hybrid poplar (Populus spp.) and hybrid larch (Larix $\times$ eurolepis Henry). Between 1980 and 2013, about 100,000 to 150,000 ha of former farmland were converted to forests.

Generally, most farmland sites are more fertile than the forest land in Sweden where Norway spruce grows. Spruce stands on farmland have a rapid growth early in the rotation and mostly produce 50-100 $\mathrm{m}^{3} \mathrm{ha}^{-1}$ more than corresponding forest land [1]. Therefore, the stem density could be maintained at a higher level without yield reduction. Danish experiments [2-6] have shown a decrease in growth after 30-40 years for spruce stands growing on clay soils. These stands were more frequently damaged by root rot (Heterobasidion annosum (Fr.) Bref.) and more susceptible to windthrow. In Sweden, there have been only limited studies of how yield production is linked with soil type for Norway spruce growing on farmland. In a study of planted Norway spruce, Johansson [7] found that, in most parts of Sweden, the survival rate of seedlings was lower when planted on heavy clay soils than on other soil types. Most of these stands were located in southern Sweden. Reports from their owners indicated that the growth of stands planted on sediments of heavy clay soils slowed down and some stands suffered mortality losses when they were 30 to 40 years old.

Johansson [8] has described studies of biomass production using Norway spruce growing on former farmland. Site index curves for Norway spruces growing on former farmland in Nordic countries have been reported by Klem [9], Andersen [10], Nielsen and Helles [11] and Johansson [7,12]. Studies of stem volume production for Norway spruce growing on forest land under Nordic conditions have been carried out in the latter half of the 20th century [13-15]. However, many published studies have been about trees with a diameter at breast height less than $15 \mathrm{~cm}$. There have been few studies of the development of stem volume equations for Norway spruce growing on former farmland although stem volume equations for Norway spruce growing on farmland in Iceland have been developed [16]. Norway spruce stands growing on fertile soils, which dominate in agricultural areas, generally show rapid growth early in the rotation, sometimes producing high yields.

There is a need for an equation to estimate the commercial part of Norway spruce stems growing on farmland. Merchantable volume equations for predicting commercial volumes have been developed [17-19]. There are two types of equations for prediction of commercial stem volume: one based on top diameter, the other on the bole length. Estimations can then use either a merchantable volume equation or a taper equation. 


\section{Objectives}

The first aim was to develop a stem volume equation for Norway spruce growing on farmland sites. The equation was based on diameter at breast height and stem height. The volumes predicted by the equation were compared with predicted volumes from commonly-used equations for forest land. The volume production of the studied stands was calculated and compared with reported volumes from stands growing on farm and forest land. The second aim was to develop a merchantable volume equation using top diameter and bole length as predictive variables.

\section{Materials and Methods}

\subsection{Study Site}

In this study, data from two previous studies have been used. In one study, data from 115 Norway spruce stands growing on planted farmland between 1903 and 1971 (21-91 years of age) were collected in 1994 and published by Johansson [7,12] and, in the other-a study of biomass production [8] — data from 30 stands established between 1943 and 1980 (17-54 years of age) were collected in 1997. Figure 1 shows the location of the studied stands. They ranged in age from 17 to 91 years and the planted areas were $0.5-1.5$ ha in size. The seedlings (bare roots) were 3-4 years old when they were planted. The year of planting was known for all stands. Only stands free from damage caused in their adult and mature period of development were selected. Information was provided by the owner. The mean number of stems per ha was calculated based on the numbers of stems counted in five randomly established $100 \mathrm{~m}^{2}(10 \times 10 \mathrm{~m})$ plots. On each of the plots, the diameter at breast height $(\mathrm{DBH})$ and tree height were recorded for all trees (in total 4054 trees) and the mean for the stand calculated (Table 1). Most of the stands had been thinned once or twice prior to the study and a smaller number had not been thinned at all. The harvested volume in a stand was not known. The site index (SI, $\mathrm{H}_{40} \mathrm{~m}$ total age) for each of the stands was estimated [7].

Figure 1. Locations of the sampled Norway spruce trees growing on former farmland.

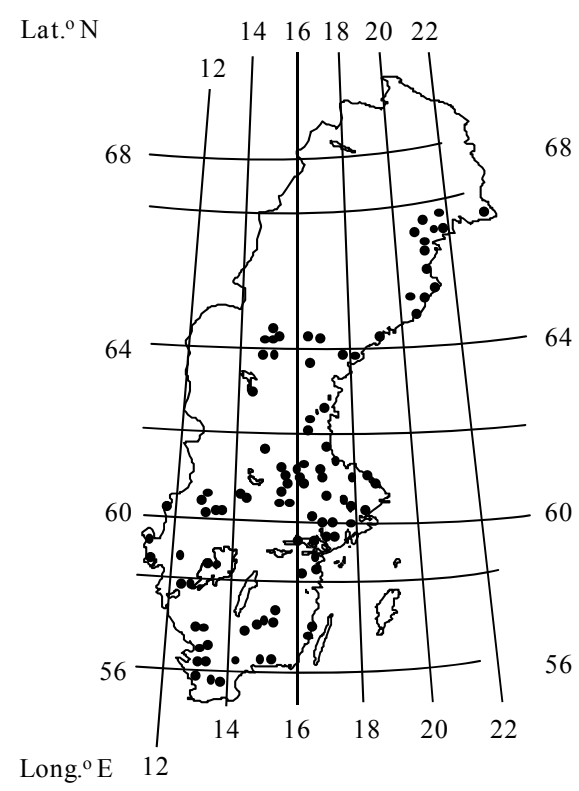




\subsection{Soil Sampling}

Two soil samples $(500 \mathrm{~g})$ were taken at random from each stand to a depth of $30 \mathrm{~cm}$ and the mean texture of the sampled layer was determined. Soils were classified in the field as tills or sediments [8] according to Ekström [20] and then by particle size in the laboratory. The particle size distribution was determined using a mechanical sieving method (English and German standard), and soil textural classes were classified as follows: (a) sediments - gravel (20-2 mm), coarse sand (2-0.2 $\mathrm{mm})$, fine sand $(0.2-0.02 \mathrm{~mm})$, silt $(0.02-0.002 \mathrm{~mm})$, or clay $(<0.002 \mathrm{~mm})$; (b) tills-gravel, sandy, fine sandy, or silty; and (c) organogenic soils-moorland peat or moss peat. Although the soil samples contained particles of different sizes, their type designation was based on the most frequent particle size present, and this was combined with one or two prefixes associated with other less frequent soil particle sizes. Clay soils were then classified based on their percentage clay, as follows: light clay (13\%-29\%), medium clay $(30 \%-40 \%)$, heavy clay $(41 \%-60 \%)$, and till clay $(13 \%-60 \%)$. The soil profile was analyzed and the mineral soil type recorded for all stands. The soil types recorded in the previous studies [7,8,12] were included in this study (sample size in parentheses): coarse sand (22), fine sand and silt (34), light clay (24), medium clay (8), heavy clay (9), sandy till (15), fine sandy till (8), silty till (21) and peat (4). The mean annual increment (MAI) was calculated.

Table 1. Summary statistics for 145 stands and sample trees of Norway spruce.

\begin{tabular}{|c|c|c|c|c|c|}
\hline Variable & Unit & Mean & SD & Min. & Max. \\
\hline \multicolumn{6}{|c|}{ Stand characteristics } \\
\hline Total age & years & 40 & 13 & 17 & 91 \\
\hline Age to reach DBH & years & 9 & 2 & 3 & 15 \\
\hline Stem number & stems ha ${ }^{-1}$ & 1621 & 902 & 100 & 7600 \\
\hline Diameter (DBH) & $\mathrm{cm}$ & 15.4 & 4.0 & 5.1 & 26.8 \\
\hline Height & $\mathrm{m}$ & 16.1 & 4.0 & 6.6 & 26.6 \\
\hline Basal area & $\mathrm{m}^{2} \mathrm{ha}^{-1}$ & 27.1 & 11.5 & 2.9 & 64.1 \\
\hline Site index & $\mathrm{H}_{40}, \mathrm{~m}$ & 19 & 2 & 15 & 24 \\
\hline Stand area & ha & 0.9 & 0.2 & 0.3 & 2.1 \\
\hline Total no of mes & Ired trees & 4054 & & & \\
\hline \multicolumn{6}{|c|}{ Sample tree characteristics } \\
\hline Diameter (DBH) & $\mathrm{cm}$ & 15.7 & 3.9 & 5.4 & 24.9 \\
\hline Height & $\mathrm{m}$ & 15.6 & 4.0 & 6.1 & 25.7 \\
\hline Stem volume & $\mathrm{m}^{3}$ & 0.170 & 0.110 & 0.018 & 0.503 \\
\hline Plot area & $\mathrm{m}^{2}$ & 500 & & & \\
\hline \multicolumn{2}{|c|}{ No of sampled trees } & 145 & & & \\
\hline
\end{tabular}

\subsection{Construction of Stem Volume and Merchantable Volume Equations for Norway Spruce}

There are several methods for estimating stem volume [21-24]. Sections (1-3 m) of the stem can be used to calculate stem volume using several different formulae [21]. Summing of the section volumes and the top volume (using the cone formula) gives the tree volume. Equations based on basal area at breast height, tree height and a form factor are common volume estimation tools c.f. Näslund [25]. 
An undamaged tree of average diameter in the stand ( 5 plots) was chosen and felled. The tree was cut as close to the ground as possible to make the measurement of tree height easier. The diameter and height of the sampled trees were measured and the total age (age from seed) and age at DBH were recorded (Table 1). The volume of each sample tree was calculated by summing the volume $\left(\mathrm{m}^{3}\right)$ of $1 \mathrm{~m}$ sections using Smalian's formula $\left(v=\left(\left(A_{1}+A_{2}\right) / 2\right) \times 1\right) \mathrm{m}^{3}$ where $A\left(\mathrm{~m}^{2}\right)$ is the stem area at the ends of the section). The volume of the top section was calculated using the formula of a cone. The mean observed stem volume for the sampled Norway spruce trees was $0.170 \pm 0.110\left(0.018-0.503 \mathrm{~m}^{3}\right)$ (Table 1).

Equations for the stem volume that used diameter or diameter and height were tested. In the initial test, nine equations were tested.

For developing merchantable volume equations that use top diameter and bole length as variables data for total height, section volume, section diameter and $\mathrm{DBH}$ from the measured $1 \mathrm{~m}$ sections were used.

Initially, three published merchantable volume equations for predictions of bole top and bole length were tested. Only one of each fitted the data well.

Then the following four equations were examined further:

$$
\begin{aligned}
& v=\beta_{0} D^{\beta_{1} \beta_{2} H^{2}} \\
& v=\beta_{0} e \beta_{1}+H^{\beta_{2}} \\
& v_{m}=v\left(1-\beta_{0}{ }^{\beta_{m}}{ }_{1} D B H_{2}\right) \\
& v_{m}=v\left(1-\beta_{0}\left(\left(H-h_{m}\right) \beta_{1 / H} \beta_{2}\right)\right)
\end{aligned}
$$

where: $v=$ total stem volume, $\mathrm{m}^{3} ; v_{m}=$ merchantable volume, $\mathrm{m}^{3} ; D B H=$ diameter at breast height (ob), $\mathrm{cm} ; d_{m}=$ top diameter $(\mathrm{ob}), \mathrm{cm} ; H=$ stem height, $\mathrm{m} ; h_{m}=$ merchantable height, $\mathrm{m} ; \beta_{0}, \beta_{1}$ and $\beta_{2}$ are parameters.

\subsection{Statistical Analysis}

Data were analyzed with nonlinear regression using the SAS/STAT system for personal computers [27].

$\begin{array}{lll}\text { Coefficient of determination } & R^{2} & 1-\frac{1}{n} \sum\left(v_{i}-\hat{v}_{i}\right)^{2} / \sum_{i=1}^{n}\left(v_{i}-\bar{v}\right)^{2} \\ \text { Average bias } & \text { AB } & \frac{1}{n} \sum_{i=1}^{n}\left(v_{i}-\hat{v}_{i}\right) \\ \text { Average Absolute Bias } & \text { AAB } & \frac{1}{n} \sum_{i=1}^{n}\left|v_{i}-\hat{v}_{i}\right|\end{array}$


Root Mean Square Error $\quad$ RMSE $\sqrt{\sum_{i=1}^{n} \frac{\left(v-\hat{v}_{i}\right)^{2}}{n}}$

where: $v_{i}, \bar{v}$ and $\hat{v}_{i}$ are the observed, mean and predicted volumes $(v)$.

Each of the equations was also tested using average bias, (AB), average absolute bias (AAB), root mean square error (RMSE) and residual plots. According to Parresol et al. [29] AAB reveals a clear distinction between the equations examined.

The validity of a model can be assessed using an independent dataset [30]. The predictive capacity of a model was examined using a "leave-one-out cross validations" procedure [31]. Data points for the entire experiment were omitted one at a time and the parameters were estimated using the reduced data set.

Using a $t$-test, a multiple comparison of mean MAIs among soil types for the sampled stands was carried out. The level of significance accepted was $\alpha \leq 0.05$.

Throughout the results, means in statistical tests are presented along with their standard errors (SE) and predicted stem volumes with their standard deviations (SD).

\section{Results and Discussion}

\subsection{General Characteristics}

As some of the stands had not been thinned, the growth may have been influenced by competition, resulting in lower growth. The correlations between $\mathrm{DBH}$ and tree height for the sample trees, and DBH and observed stem volumes are shown in Figure 2.

Figure 2. Relationship between diameter at breast height $(\mathrm{DBH}), \mathrm{cm}$ and tree height, $\mathrm{m}$, (a) and between DBH and stem volume, $\mathrm{m}^{3}(\mathbf{b})$.

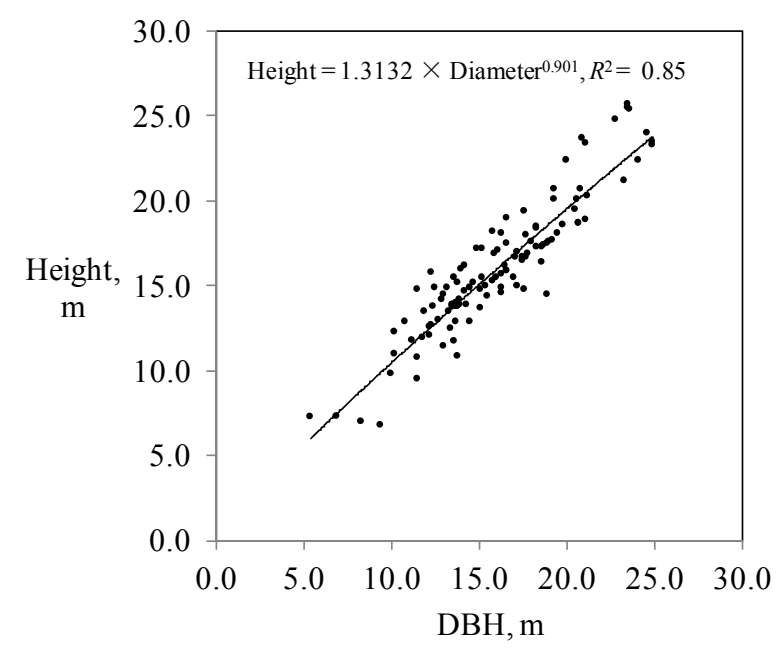

$\mathbf{a}$

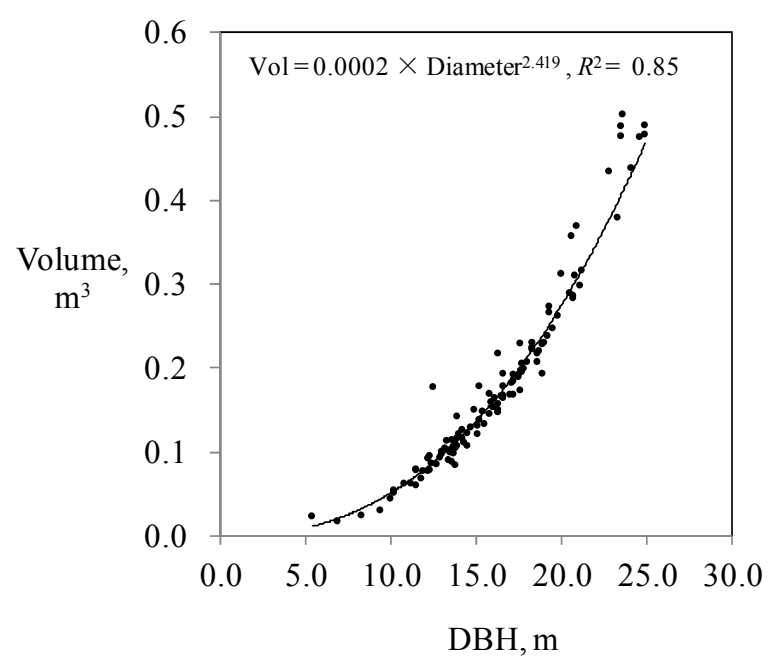

b 


\subsection{Stem Volume Equations for Norway Spruces}

Based on the dataset (Table 1), parameter estimates were determined for Equations 1 and 2. The equation was restricted to Norway spruce trees having a $\mathrm{DBH} \geq 5 \mathrm{~cm}$. As shown in Table 2, the asymptotic standard errors for the parameter estimates were lower than for the estimated parameter values. The predicted stem volumes were $0.172 \pm 0.101(0.001-0.479)$ and $0.181 \pm 0.105$ $(0.033-0.540) \mathrm{m}^{3}$ for the Equations $(1-2)$ tested. The coefficient of determination $\left(R^{2}\right)$ for both equations was high $(97 \%)$.

Table 2. Estimated parameters of Equations 1-4.

\begin{tabular}{|c|c|c|c|c|c|c|}
\hline Parameter & $\begin{array}{c}\text { Parameter } \\
\text { estimate }\end{array}$ & $\begin{array}{c}\text { Standard errorof } \\
\text { parameter }\end{array}$ & $\mathbf{A A B}$ & $R^{2}$ & RMSE & RMSE $^{1}$ \\
\hline & & Equation (1) & & & & \\
\hline$\beta_{0}$ & 0.000238 & 0.000050 & 0.023 & 0.97 & 0.0356 & 0.0356 \\
\hline$\beta_{1}$ & 0.061800 & 0.025600 & & & & \\
\hline \multirow[t]{2}{*}{$\beta_{2}$} & 2.310900 & 0.069300 & & & & \\
\hline & & Equation (2) & & & & \\
\hline$\beta_{0}$ & 0.00087 & 0.000080 & 0.026 & 0.97 & 0.0377 & 0.0377 \\
\hline$\beta_{1}$ & 0.06270 & 0.023500 & & & & \\
\hline \multirow[t]{2}{*}{$\beta_{2}$} & 0.50860 & 0.006240 & & & & \\
\hline & & Equation (3) & & & & \\
\hline$\beta_{0}$ & 0.13500 & 0.003440 & 0.002 & 0.99 & 0.0057 & 0.0055 \\
\hline$\beta_{1}$ & 3.21760 & 0.011000 & & & & \\
\hline \multirow[t]{2}{*}{$\beta_{2}$} & -2.65280 & 0.012500 & & & & \\
\hline & & Equation (4) & & & & \\
\hline$\beta_{0}$ & -0.95760 & 0.011700 & 0.001 & 0.99 & 0.0031 & 0.0029 \\
\hline$\beta_{1}$ & 2.63690 & 0.004850 & & & & \\
\hline$\beta_{2}$ & 2.62680 & 0.006410 & & & & \\
\hline
\end{tabular}

A comparison was made between observed volumes $\left(\mathrm{V}_{\mathrm{o}}\right)$ and predicted volume $\left(\mathrm{V}_{\mathrm{p}}\right)$ for the two equations. The residual distribution fitted the data with a range of -0.077 to $0.063 \mathrm{~m}^{3}$ for equation 1 and -0.068 to $0.092 \mathrm{~m}^{3}$ for equation 2, Figure 3 . AAB was $0.024 \mathrm{~m}^{3}$ for equation (1) and 0.026 for equation (2). The RMSE was 0.0356 and $0.0377 \mathrm{~m}^{3}$, respectively, for Equations (1) and (2). In the "leave-one-out cross validation" procedure, the RMSE was the same as that for the fitted models (Table 2). Further information about parameter estimates is given in Table 2. Based on the criteria above, it was determined that equation 1 would be preferred when estimating stem volume of Norway spruces growing on former farmland sites. 
Figure 3. Residuals for the stem volume Equation 1 (a) and Equation 2 (b) for Norway spruce.

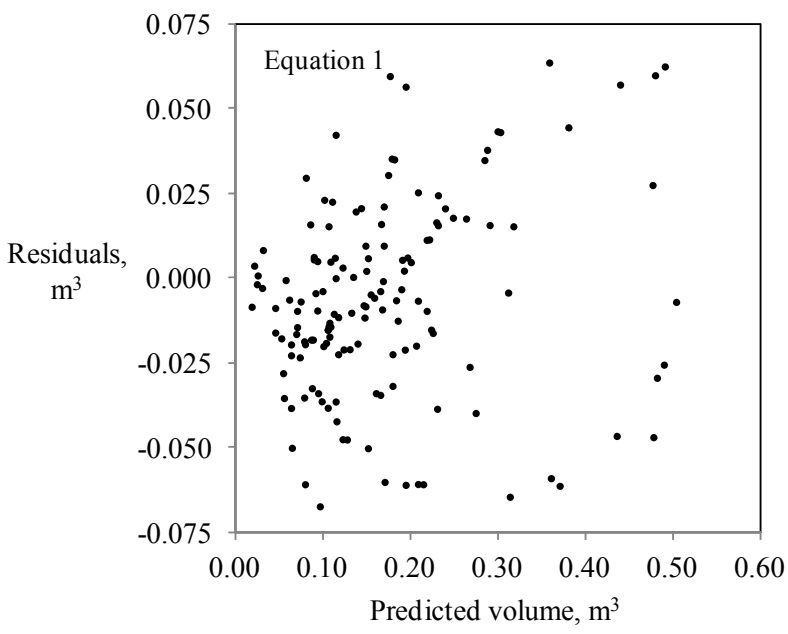

a

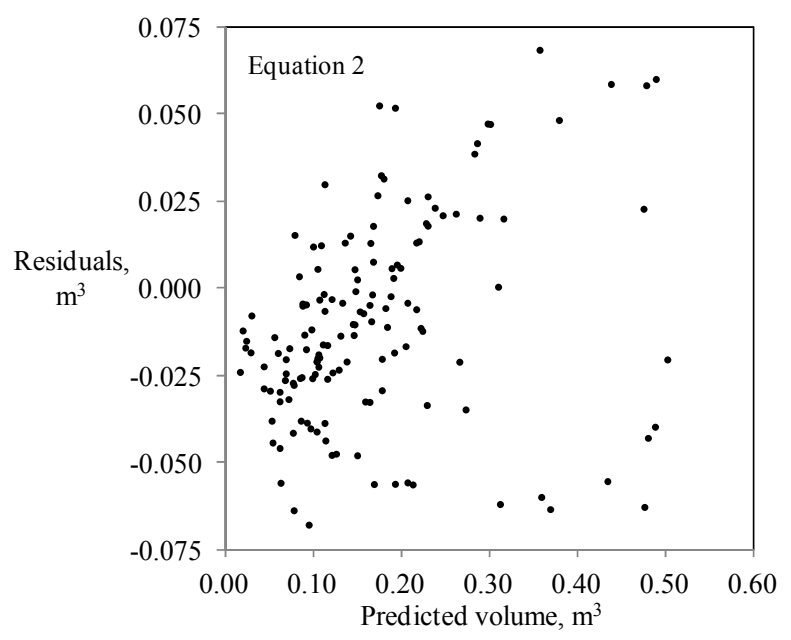

b

\subsection{Comparison between Estimated Stem Volume using Equation (1) and Five Commonly-Used Equations}

Estimates of stem volume using equation (1) and five other commonly-used equations for Norway spruce were compared with the stem analysis volume estimates (observed).

The following equations were tested:

An equation for single Norway spruce stems growing on former farmland in Iceland:

$$
V=0.1299 \times D B H^{1.6834} \times H^{0.8598}
$$

Two stem equations for Norway spruce growing on forest land in Sweden:

$$
\begin{gathered}
V=0.1150 \times D B H^{2}+0.01746 \times D B H^{2} \times H+0.02022 \times D B H H^{2}-0.05618 \times H^{2} \\
V=10^{-1.0039} \times D B H^{2.00128} \times(D B H+10.0)^{-0.47473} \times H^{2.87138} \times(H-1.3)^{-1.61803}
\end{gathered}
$$

A stem equation for Norway spruce growing on forest land in Norway:

$$
V=6.69+0.01308 \times D B H^{2} \times H+0.02853 \times D B H H^{2}-0.31956 \times H^{2}+0.28969 \times D B H H
$$

A stem equation for Norway spruce growing on forest land in Finland:

$$
V=0.0022927 \times\left(D B H^{1.91505}\right) \times\left(0.99146^{D B H}\right) \times\left(H^{2.82541}\right) \times(H-1.3)^{-1.53547}
$$

where $D B H=$ diameter at breast height, $\mathrm{cm} ; H=$ height, $\mathrm{m} ; v=$ total volume, $\mathrm{m}^{3}$.

As evident in Table 3, the estimated volumes for equation (1) were closest to the observed volumes. Equations 9 and 11 underestimated stem volumes (93\% and 94\% by observed), while Equations 10, 12 and 13 overestimated stem volumes $(109 \%, 110 \%$ and 106\%, respectively). The local volume equation was more accurate than the compared equations. Apart from the Icelandic equation (9), the other equations were based on data from stands growing on forest land. The two Swedish Equations (10 and 11), developed for trees growing on forest land, overestimated and underestimated the stem volumes respectively. The diameter-height relationship might be different between the trees growing 
on a homogenous farmland site with only a single species compared to mixed species stands on native forest land sites.

Table 3. Comparison of observed stem volumes for Norway spruce between the constructed Equation 1 and Equations 9-13.

\begin{tabular}{|c|c|c|c|c|c|c|c|}
\hline & \multicolumn{7}{|c|}{ Stem volume, $\mathbf{m}^{3}$} \\
\hline & Observed & Equation 1 & Equation 9 & Equation 10 & Equation 11 & Equation 12 & Equation 13 \\
\hline Mean & 0.170 & 0.172 & 0.159 & 0.186 & 0.160 & 0.187 & 0.181 \\
\hline SD & 0.110 & 0.101 & 0.099 & 0.135 & 0.120 & 0.137 & 0.131 \\
\hline Range & $0.018-0.503$ & $0.001-0.470$ & $0.012-0.439$ & $0.010-0.595$ & $0.007-0.524$ & $0.022-0.606$ & $0.010-0.0 .573$ \\
\hline
\end{tabular}

\subsection{Standing Volume for Norway Spruce Stands}

The average stem volumes of all plots were estimated and divided by the plot area, and converted to volume per hectare. The mean standing volume was $253 \pm 103$ (range 26-517) $\mathrm{m}^{3} \mathrm{ha}^{-1}$. Standing mean annual increment (MAI) was $6.90 \pm 3.49$ (range 1.25-16.68) $\mathrm{m}^{3} \mathrm{ha}^{-1}$ year $^{-1}$. In Nordic countries, few studies exist that relate volume production of Norway spruce stands growing on farmland sites. Reynisson [33] studied the yield of Norway spruce planted on pasture and farmlands in Iceland. In his study, the mean standing yield was 196 (range 104-260) $\mathrm{m}^{3} \mathrm{ha}^{-1}$ and the MAI was 4.3 (range 3.4-5.5) $\mathrm{m}^{3} \mathrm{ha}^{-1}$ year $^{-1}$. In a study of 30-year-old Norway spruce growing on former farmland in Sweden, a forecast of future yields (40-80 years) was made based on data from 30-year-old trees [1]. The MAI culminated at 50 years of age. In a study of planted Norway spruce growing on former pasture land in the Southeast of Sweden (Lat. $58^{\circ} 11^{\prime}$ N., Long. $15^{\circ} 54^{\prime}$ S., Alt. 130 a.s.1.), the standing volume after a rotation of 78 years was $534 \mathrm{~m}^{3} \mathrm{ha}^{-1}$ for unthinned and $433 \mathrm{~m}^{3} \mathrm{ha}^{-1}$ for low thinned (six times) stands [34]. The corresponding MAI values were 6.85 and $5.55 \mathrm{~m}^{3} \mathrm{ha}^{-1}$ year ${ }^{-1}$, respectively. Braathe [35] studied the influence of spacing on the establishment and yield of Norway spruce planted on former farmland in Norway. The standing volume was 318 and $427 \mathrm{~m}^{3} \mathrm{ha}^{-1}$ after 44 and 48 years of age, with an MAI of 7.23 and $8.90 \mathrm{~m}^{3} \mathrm{ha}^{-1}$ year $^{-1}$, respectively.

\subsection{Relationship Between Soil Types and MAI}

The mean annual increment for soil types and stands varied (Table 4).

Table 4. Mean annual increment, $\mathrm{m}^{3} \mathrm{ha}^{-1}$ year $^{-1}$ for Norway spruce (Picea abies (L.) Karst.) stands growing on farmland with different soil types.

\begin{tabular}{|c|c|c|c|c|c|c|c|c|}
\hline \multicolumn{3}{|c|}{ Clay } & \multicolumn{3}{|c|}{ Till } & \multirow{2}{*}{$\begin{array}{l}\text { Coarse } \\
\text { Sand * }\end{array}$} & \multirow{2}{*}{$\begin{array}{l}\text { Fine sand } \\
\text { and silt * }\end{array}$} & \multirow[b]{2}{*}{ Peat * } \\
\hline Light * & Medium * & Heavy & Sandy & $\begin{array}{c}\text { Fine } \\
\text { sandy }\end{array}$ & Silty & & & \\
\hline $7.62 \pm 4.24$ & $6.90 \pm 2.26$ & $6.63 \pm 2.56$ & $6.21 \pm 2.89$ & $6.17 \pm 3.39$ & $4.94 \pm 2.27$ & $7.46 \pm 3.33$ & $7.59 \pm 4.13$ & $8.67 \pm 2.83$ \\
\hline $2.22-13.32$ & $1.59-17.61$ & $1.53-16.68$ & $3.09-9.69$ & $2.94-9.42$ & $2.46-10.76$ & $1.25-12.43$ & $1.25-13.16$ & $5.63-11.69$ \\
\hline
\end{tabular}


A $t$-test (LSD) at 5\% level indicated that there were significant differences in MAI between silty till and coarse sand, light clay, medium clay and peat (Table 4). The MAI for stands growing on peat soils was high. These areas were previously ditched and fertilized as part of the agricultural management of cereal crops. The high MAI values for the peat soils suggest that the Norway spruce stands benefitted from residual soil fertility from past land use. Johansson and Karlsson [1] presented MAI values for 17 planted Norway spruce stands growing on farmland in southern and middle Sweden. The mean MAI for 26 to 31-year-old stands was $8.58 \pm 2.86$ (range 4.37-13.26) $\mathrm{m}^{3} \mathrm{ha}^{-1}$ year ${ }^{-1}$. Stands growing on fine sandy tills had the highest levels of MAI (10.73 and $13.26 \mathrm{~m}^{3} \mathrm{ha}^{-1}$ year $^{-1}$ ). In a study by Alriksson and Olsson [36], levels of MAI for 20, 40 and 55-year-old Norway spruce stands growing on farmland sites (Lat. 58 $32^{\prime}$ N.) were 11.0, 10.0 and $8.0 \mathrm{~m}^{3} \mathrm{ha}^{-1}$ year $^{-1}$, respectively. The plantations were established on sandy loam soils.

\subsection{Merchantable Volume Equations for Norway Spruces}

Parameter estimates were determined for Equations (3) and (4). The asymptotic standard errors for the parameters were lower than for the estimated parameter values, Table 2. Overall, the equations fitted the data well. The $R^{2}$ values were high, 0.99, for both equations. The AAB was low, 0.002 and 0.001 , respectively for the equations. In the "leave-one-out cross validation" procedure, the RMSE was lower, 0.0055 and 0.0029 , than RMSE for the fitted equations (0.0057 and 0.0031). The residual distribution fitted the data with a narrow range of -0.019 to 0.025 for Equation (3) and -0.017 to 0.032 for Equation (4), Figure 4. Both equations slightly underestimated the volumes. The top diameter and bole length merchantable volume equations represent important tools for estimating the commercial stem volume of Norway spruce in Sweden.

Figure 4. Residuals for the merchantable volume Equations (3) (a) and (4) (b) for Norway spruce.

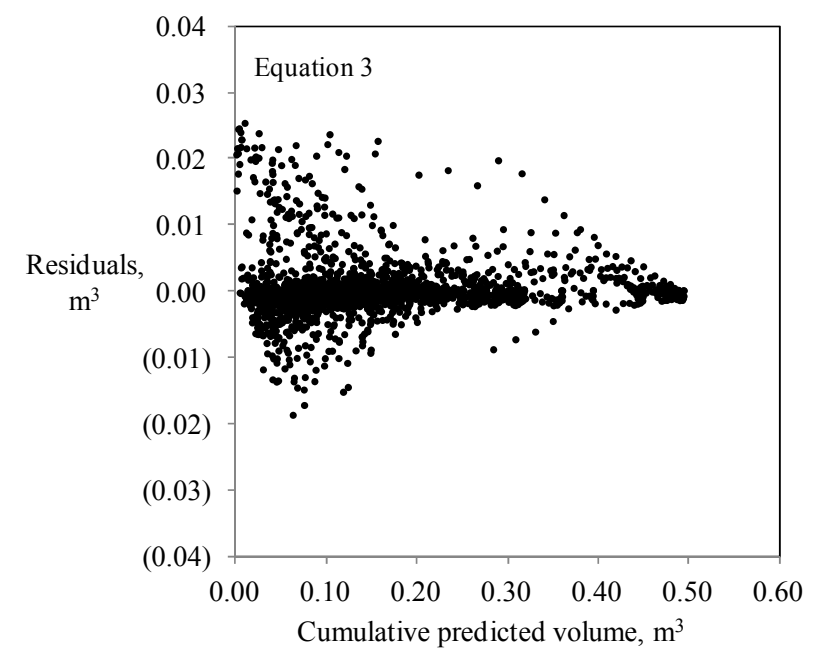

a

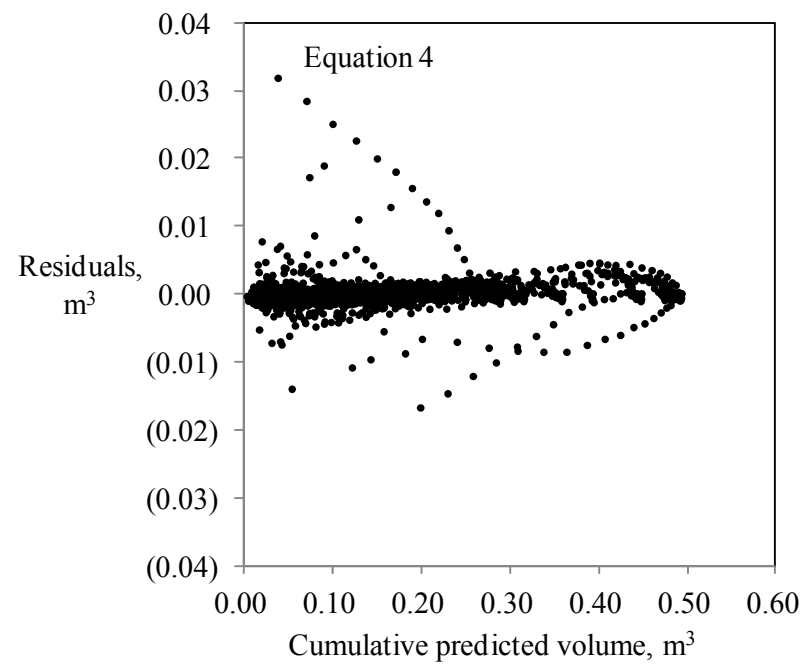

b 


\section{Conclusions}

Stem volume estimates for Norway spruce growing on former farmland sites were calculated using a newly developed equation and two commonly-used equations. Results suggested that the latter equations underestimated stem volume. Two other equations developed for forest land use overestimated the observed stem volumes. As the volume accumulations were 50 to $100 \mathrm{~m}^{3} \mathrm{ha}^{-1}$ higher on former farmland than forest sites, the newly developed stem volume equation for Norway spruce represents a more accurate alternative to using existing equations when applied to farmland sites.

The stem volume equation developed for Norway spruce growing on former farmland sites, using DBH and stem height as independent variables, fits the data well. The preferred equation was valid for trees having a DBH larger than $5 \mathrm{~cm}$ and less than $30 \mathrm{~cm}$. Calculation of stem volume for spruce trees with a $\mathrm{DBH}>30 \mathrm{~cm}$ should be carried out with care. Measuring stem height is more time-consuming and laborious than DBH. A commonly-used method is to sample tree heights per diameter class. Based on the diameter to height correlation, the stem height for all diameters in the stand or plot can be calculated.

The merchantable volume prediction equations fitted the data well. The flexible top diameter and bole length merchantable volume equation represents a useful tool for the estimation of commercial parts of a stem. As well as the calculation of timber volume in mature stands, the forest owner can use the merchantable equations for estimating timber volumes when cutting young spruce stands that have small dimensions. In most cases, there must be a certain volume of timber after harvesting to make a profit, otherwise the tree should be harvested as pulpwood. When the log volumes have been predicted, the top volume could be calculated by subtracting the timber and pulpwood volume from the total bole volume. Then the top volume, used as biomass, could be calculated by using the basic density $\left(\mathrm{m}^{3} \mathrm{~kg}^{-1}\right)$.

\section{Acknowledgments}

I wish to thank Kurt-Arne Öh and Hans Brandt for measuring the stands and three anonymous reviewers for constructive criticisms. Linguistic revisions were carried out by Sees-Editing Ltd UK. Financial support was provided by the Swedish Council for Forestry and Agricultural Research. All of the above are gratefully acknowledged.

\section{Conflicts of Interest}

The author declares no conflict of interest.

\section{References}

1. Johansson, T.; Karlsson, K. Yield of 30-year-Old Norway Spruce (Picea abies (L.) Karst.) Planted on Farm Land in Southern and Central Sweden and Recommendations for Planting Norway Spruce on Farm Land. Swed. Univ. Agric. Sci. Dept. For. Yield Res. Rep. 1988, 21, 37.

2. Henriksen, H.A. Yield and Stability of Conifers. Dan. For. Assoc. Tidskr. 1955, 40, 571-591. 
3. Bryndum, H. Terminated Sample Plots in Norway spruce. Dan. For. Exp. Stat. 1964, 28, 261-397.

4. Bryndum, H. Yield Experiments in Norway Spruce Stands. Dan. Skovfor. Tidskr. 1965, 50, 175-192.

5. Bryndum, H. Thinning Experiments in Young Norway Spruce. Nor. For. Res. Inst. 1967, 22, 49-63.

6. Bryndum, H. Thinning trials in young stands of Norway spruce growing on clay till soils. Dan. For. Exp. Stat. 1978, 36, 1-180. (In Danish)

7. Johansson, T. Site Index Curves for Norway Spruce Plantations on Farmland with Different Soil Types. Studia For. Suecic. 1995, 198, 1-19.

8. Johansson, T. Biomass Production of Norway Spruce (Picea abies (L.) Karst.) Growing on Abandoned Farmland. Silva Fenn. 1999, 33, 261-280.

9. Klem, G.G. The Influence of Spacing on Spruce Quality. Norw. For. Res. Inst. 1952, 11, 477-506.

10. Andersen, K.F. Increasing Yield Production on Moor Plantations. Voekst 1984, 105, 11-13.

11. Nielsen, U.B.; Helles, F. Dry Mass Production of Norway Spruce. Dan. Skovbrugsfor. Tidskr. 1991, 76, 97-113.

12. Johansson, T. Site Index Curves for Norway Spruce (Picea abies (L.) Karst.) Planted on Abandoned Farm Land. New For. 1996, 11, 9-29.

13. Eriksson, H. Yield Production of Norway Spruce in Sweden. Royal Coll. For. Rep. 1976, 41, 291.

14. Laasasenaho, J. Taper Curve and Volume Functions for Pine, Spruce and Birch. Commun. Inst. For. Fenn. 1982, 108, 1-74.

15. Brandel, G. Volume Functions for Individual Trees, Scots Pine (Pinus sylvestris), Norway Spruce (Picea abies) and Birch (Betula pendula \& Betula pubescens). In Rapport-Institutionen för Skogsproduktion, Sveriges Lantbruksuniversitet; Swedish University of Agricultural Sciences: Garpenberg, Sweden 1990.

16. Snorrason, A.; Einarsson, S.F. Single Tree Biomass- and Stem Volume Functions for Eleven Tree Species Used in Icelandic Forestry. Icel. Agric. Sci. 2006, 19, 15-24.

17. Clutter, J.L. Development of Taper Functions from Variable-top Merchantable Volume Equations. For. Sci. 1980, 6, 117-120.

18. Burkhart, H.E. Cubic-foot Volume of Loblolly Pine to any Merchantable Top Diameter. South. J. Appl. For. 1977, 1, 7-9.

19. Terwari, V.P.; Mariswamy, K.M.; Arunkumar, A.N. Total and Merchantable Volume Equations for Tectona grandis Linn. f. Plantations in Karnataka, India. J. Sust. For. 2013, 32, 213-229.

20. Ekström, G. Classification of Swedish Soil Types on Farm Land. SGU. Rep. 1926, 345, 1-161. (In Swedish)

21. Clutter, J.L.; Fortson, J.C.; Pienaar, L.V.; Brister, G.H.; Bailey, R.L. Timber Management: $A$ Quantative Approach; John Wiley \& Sons: New York, NY, USA, 1983.

22. Prodan, M. Holzmesslehre; Sauerlaender's Verlag: Frankfurt am Maine, Germany, 1965.

23. Prodan, M.; Peters, R.; Cox, F.; Real, P. Mensura Forestal. German Association for Cooperation (GTZ) FMBH; Institute for Cooperation on Agriculture (IICA): San José, Costa Rica, 1997. 
24. Young, H.E.; Robbins, W.C.; Wilson, S. Errors in Volume Determination of Primary Products. In Proceeding of the 14th Eufro Congress, Munich, Germany, 4-9 September 1967; pp. 546-562.

25. Näslund, M. Functions and Tables for Computing the Cubic Volume of Standing Trees. Messag. State For. Res. Ins. 1947, 36, 81.

26. Cao, Q.V.; Burkhart, H.E.; Max, T.A. Evaluation of Two Methods for Cubic-volume Prediction of Loblolly Pine to Any Merchantable Limit. For. Sci. 1980, 26, 71-80.

27. SAS; Version 9.1; SAS Institute Inc.: Cary, NC, USA, 2006.

28. Zar, J.H. Biostatistical Analysis; Prentice Hall: Englewood Cliffs, NJ, USA, 1999.

29. Parresol, B.R.; Hotvedt, J.E.; Cao, Q.V. A Volume and Taper Prediction System for Bald Cypress. Can. J. For. Res. Res. 1987, 17, 250-259.

30. Kozak, A.; Kozak, R. Does Cross Validation Provide Addition Information in the Evaluation of Regression Models? Can. J. For. Res. 2003, 33, 976-987.

31. Nord-Larsen, T.; Meilby, H.; Skovsgaard, J. Site Specific Height Growth Models for Six Common Tree Species in Denmark. Scand. J. For. Res. 2009, 24, 194-204.

32. Vestjordet, E. Equations and Tables for Computing the Cubic Volume of Standing Spruces. Medd. Nor. Skogfor. Ves. 1967, 84, 539-574.

33. Reynisson, V. Comparison of Yield of Norway Spruce (Picea abies) and Sitka Spruce (Picea sitchensis) in Skorradalur, West Iceland. Master Thesis, Swedish University of Agricultural Sciences, Alnarp, Sweden, 2011.

34. Johansson, T.; Karlsson, K. Experiment with Different Thinning Intensity and Thinning Interval in Stands of Norway Spruce. Swed. Univ. Agric. Sci. Dept. Bioenergy 2004, 4, 44.

35. Braathe, P. The Influence of Spacing on Establishment and Volume Production in Spruce Forest. Medd. Nor. Skogsfor. Ves. 1952, 11, 429-469.

36. Alriksson, A.; Olsson, M.T. Soil Changes in Different Age Classes of Norway spruce (Picea abies (L.) Karst.) on Afforested Farm Land. Plant Soil 1995, 62, 103-110.

(C) 2014 by the authors; licensee MDPI, Basel, Switzerland. This article is an open access article distributed under the terms and conditions of the Creative Commons Attribution license (http://creativecommons.org/licenses/by/3.0/). 